\title{
Partnership between platelet-rich plasma and mesenchymal stem cells: in vitro experience
}

\author{
Eva Rubio-Azpeitia \\ Isabel Andia
}

Regenerative Medicine Laboratory, BioCruces Health Research Institute/Cruces University Hospital, Barakaldo, Spain

Corresponding author:

Isabel Andia

Regenerative Medicine Laboratory,

BioCruces Health Research Institute/Cruces

University Hospital

Pza Cruces s/n

48903 Barakaldo, Spain

E-mail: iandia2010@ hotmail.com

\section{Summary}

We aim to identify current in vitro research exploring platelet-rich plasma (PRP) effects in human Mesenchymal Stem Cells (MSCs) that may encourage or limit the clinical application of MSCs along with PRP. After a systematic search, we identified 57 in vitro studies, focused on optimization of MSC manufacturing, and expanding knowledge about how PRP modifies MSCs behavior for translational purposes. Influences of PRP on proliferation, migration, stemness, preservation of MSC immune-modulatory properties and appearance of senescence phenotype have been explored. Overall PRP stimulates MSC proliferation, preserves MSCs multipotency and does not interfere with any lineage differentiation. PRP (as platelet lysate or releasate) preserves the immune-privileged potential of MSCs and may delay the appearance of the senescent phenotype. Currently there are few data linking precise molecules and biological mechanisms. Various gaps of knowledge need to be addressed in order to obtain enough useful information for translational purposes.

KEYWORDS: cell culture, in vitro, mesenchymal stem cells $(M S C)$, platelet-rich plasma $(P R P)$, regenerative medicine, tissue engineering.

\section{Introduction}

The use of mesenchymal stem cells (MSCs) for tissue healing and Regenerative Medicine research has been extended in the last decade. Three accepted MSCs capabilities are centrally involved in their regenerative properties. First, their potential to differentiate into tissue specific cells, second their ability to influence the fate of other cell types through paracrine signaling and third their immune-modulatory potential through secretion of prostaglandins such as PGE2 ${ }^{1}$. It was Caplan² in 1991 who proposed the MSC definition, currently adopted by the International Society for Cellular Therapy (ISCT), based on three main criteria: first, MSC adhesion to plastic; second, their expression of a set of membrane molecules (CD73, CD90, CD105), together with a lack of expression of HLA-DR and absence of hematopoietic and endothelial markers CD11b, CD14, CD34, CD31, and CD45; and, third their ability to differentiate along adipogenic, osteogenic, and chondrogenic pathways ${ }^{3,4}$.

Current research in MSCs aims not only to the development of cell therapies in regenerative medicine, but to provide experimental models that can inform about molecular mechanisms such as inflammation, angiogenesis and apoptosis among others. For these purposes and because of their accessibility, MSCs are most commonly isolated from the bone marrow (BM$\mathrm{SC}$ ), or the adipose tissue (ADSC), and then grown in 2D or 3D conditions.

In vivo MSCs activities are regulated by the molecular microenvironments that modulate their anabolic status. Thus, signaling factors in the microenvironment instruct MSCs to remain quiescent, proliferate, migrate, and/or differentiate. In this context, autologous formulations derived from own patient's blood, named platelet rich plasma technologies are being developed to be used alone or in association with cells for regenerative medicine purposes. The foundation of PRP use is the release of a pool of signaling factors that will create a pro-healing environment in the injured site.

The first description of Platelet Rich Plasma when it was introduced as a MeSH (Medical Subject Headings) term in 2007 is: "a preparation consisting of PLATELETS concentrated in a limited volume of PLASMA. This is used in various surgical tissue regeneration procedures where the GROWTH FACTORS in the platelets enhance wound healing and regeneration". Growth factors (GFs) from PRP have their source in alpha granules from platelets $(50-80$ per platelet). However, recent proteomic studies have revealed the complexity of platelet secretome, and indexed not only GFs but a vast array of molecules including cytokines and chemokines, adhesive proteins, enzymes, fibrinolytic and antifibrinolytic proteins. This molecular pool is released upon platelet 
activation that is the interaction of molecules such as collagen, thrombin, platelet-activating factor, serotonin, calcium, magnesium, thromboxane A2, and adenosine di-phosphate with platelet receptors. Also, mechanical disruption of platelets causes their activation and the subsequent release of their content. When platelets are activated, there is an initial burst of GFs that is lately stabilized and maintained in a sustained release.

The aim of the present systematic review is to evaluate the relevance of current preclinical research towards the development of combination products (biological therapies) that may encourage or limit the clinical application of MSCs along with PRP. Therefore, we will discuss MSCs effects in proliferation, differentiation, migration and immune modulation and report on the controversial results obtained by different authors due to the heterogeneity of PRP formulations, and the different conditions used in MSCs cultures.

\section{Methods}

A systematic literature search 5 was performed from January 2007 to October 2013 in Pubmed, Web of Knowledge and Google Scholar. As keywords, we have used Platelet Rich Plasma AND/OR Platelet Lysate AND/OR Platelet Releasate AND Mesenchymal Stem Cells.

\section{Inclusion criteria}

The search was limited to "humans" and English language. Articles presenting bone as a MeSH major topic were excluded. Only original journal and classical articles (not reviews or clinical trials) were included.

\section{Extraction of data}

Title and abstracts were screened by two researchers independently, and the full text of the selected articles was read by both reviewers. The following data were extracted: cell source, platelet count, leukocyte content, whether the study was performed with the PRP from single or pooled donors, the biological mechanism that was evaluated, i.e. proliferation, differentiation, cell morphology or immunomodulation.

We classified PRPs according to the categorization system made by Delong JM et $\mathrm{al}^{6}$. Briefly, $1 \mathrm{x}$ platelet count above baseline or less is considered low platelet content, $1 \mathrm{x}-4 \mathrm{x}$ is a moderate platelet concentration, $4 \mathrm{x}-6 \mathrm{x}$ is a high content and $6 \mathrm{x}$ or more is super high content. Finally studies were sorted in two groups based on their main intended goal: 1) research studies (2D or 3D studies) and 2) cell production studies. To accomplish this goal, these authors perform long term proliferation studies and calculate cell population doublings through cell passages. They also check MSCs viability at high passages by testing phenotype, differentiation capacity and even chromosomal stability and senescence markers.

\section{Results}

\section{Study selection}

Using the above described search algorithm, we found 277 articles of which 143 articles had been performed with human cells, and were written in English. After excluding reviews and articles pertaining to dental and bone biology, and adding hand search relevant articles, we included 57 articles as relevant to research in biological mechanisms, of which 22 articles perform large scale MSC production. Twelve articles perform studies on Adipose Stem Cells (AD$\mathrm{SCs})^{7-18}$ (Tab. 1). 36 articles study PRP biological effect in BMSCs ${ }^{19-55}$ (Tab. 2), and 8 others on several stem cell types including ADSCs, BMSCs and Umbilical Cord MSCs (UCMSCs) ${ }^{56-63}$ (Tab. 3).

\section{PRP formulations}

The different procedures for PRP preparation produce different compositions that may account for result variability. Most often the two step centrifugation is used to separate blood components, and to concentrate platelets (and optionally leukocytes) in the final PRP product. Alternatively, one centrifugation step generates a PRP product with a moderate/low concentration of platelets depending on centrifugal force and time. Overall, we found that in "PRP+MSC" research there is a slightly higher use of PRPs with high or super high concentrations of platelets (Fig. 1).

\section{Leukocyte content in PRP}

Leukocyte content influences the molecular composition in PRP. However, most of the in vitro studies don't even mention leukocyte content in their final product. Leukocyte content in PRP samples is merely described by two authors 21,62 .

\section{PRP activation methods}

About $85 \%$ of the studies perform freeze/thaw cycles to cause mechanical disruption of platelet membranes and release alpha granule content. When those steps are performed, they proceed to filtration through 0.22 um filters and addition of heparin $(2 \mathrm{U} / \mathrm{ml})$ to the lysates $35,40,57$. This procedure is the most commonly found in the papers studied, but there are some authors which prefer performing chemical activation instead of thermic/mechanical activation and use of thrombin and/or calcium chloride $^{7,17,34,41,45,49}$. In general, bovine thrombin is used except for Vogl ${ }^{24}$ who obtains human thrombin from blood donations. Thrombin and/or $\mathrm{CaCl}_{2}$ trigger clot formation, and after incubation the liquid extruded from the clot is collected. This PRP fraction is called PRP releasate or supernatant. 
Table 1. Cell culture studies performed with Adipose Derived Stem Cells and Platelet Rich Plasma.

\begin{tabular}{|c|c|c|c|c|c|c|c|}
\hline \multirow[b]{4}{*}{$\begin{array}{l}\text { Author, year, } \\
\text { [reference] }\end{array}$} & \multirow[b]{4}{*}{$\begin{array}{l}\text { Platelet count } \\
\text { Pool or single } \\
\text { donor }\end{array}$} & \multicolumn{6}{|c|}{ ADIPOSE DERIVED STEM CELLS (ADSCs) } \\
\hline & & \multirow[b]{3}{*}{ Proliferation } & \multirow[b]{3}{*}{ Migration } & \multicolumn{4}{|c|}{ BIOLOGICAL EFFECTS (PRP vs FBS) } \\
\hline & & & & \multirow[b]{2}{*}{$\begin{array}{l}\text { Immune } \\
\text { modulation }\end{array}$} & \multicolumn{3}{|c|}{ Stemness } \\
\hline & & & & & Chondr. & Adipo. & Osteo. \\
\hline $\begin{array}{l}\text { Van Pham } \\
2013[7]\end{array}$ & $\begin{array}{l}\text { Super high }(6 x) \\
\text { Single donor }\end{array}$ & Enhanced & - & - & Enhanced & Similar & Similar \\
\hline $\begin{array}{l}\text { Hildner } \\
2013[8]^{\star}\end{array}$ & - & Enhanced & - & - & Enhanced & - & - \\
\hline $\begin{array}{l}\text { Chen L. } \\
2012[9]^{\#}\end{array}$ & $\begin{array}{l}\text { Super high }(6 x) \\
\text { Single donor }\end{array}$ & Enhanced & - & - & - & - & Enhanced \\
\hline $\begin{array}{l}\text { Cervelli } \\
2012[10]\end{array}$ & Pool & Enhanced & - & - & - & $\begin{array}{l}\text { Enhanced } \\
\text { with insulin }\end{array}$ & - \\
\hline $\begin{array}{l}\text { Sell } \\
2011[11]^{\#}\end{array}$ & $\begin{array}{l}\text { High }(3.82 x) \\
\text { Pool }\end{array}$ & Enhanced & Enhanced & & - & - & - \\
\hline $\begin{array}{l}\text { Shih } \\
2011[12]^{*}\end{array}$ & Single donor & Enhanced & - & - & Enhanced & Similar & Similar \\
\hline $\begin{array}{l}\text { Cholewa } \\
2011[13]^{*}\end{array}$ & $\begin{array}{l}\text { Super high }(6.2 x) \\
\text { Pool }\end{array}$ & Enhanced & - & - & - & Similar & Similar \\
\hline $\begin{array}{l}\text { Chieregato } \\
2011[14]^{\star}\end{array}$ & $\begin{array}{l}\text { Moderate }(2 \mathrm{x}) \\
-\end{array}$ & Enhanced & - & - & Similar & Enhanced & Enhanced \\
\hline $\begin{array}{l}\text { Castegnaro } \\
2011 \text { [15] }^{*}\end{array}$ & $\begin{array}{l}\text { Moderate }(2.74 x) \\
\text { Pool }\end{array}$ & Enhanced & - & Enhanced & - & Similar & Similar \\
\hline $\begin{array}{l}\text { Souza Blande } \\
2009[16]^{*}\end{array}$ & $\begin{array}{l}\text { Moderate }(3.64 x) \\
\text { Single donor }\end{array}$ & Enhanced & - & - & - & Similar & Similar \\
\hline $\begin{array}{l}\text { Kakudo } \\
2008 \text { [17] }\end{array}$ & $\begin{array}{l}\text { Super High }(7.9 x) \\
\text { Single donor }\end{array}$ & Enhanced & - & - & - & - & - \\
\hline $\begin{array}{l}\text { Kocaoember } \\
2007[18]^{*}\end{array}$ & $\begin{array}{l}\text { Super high (10x) } \\
\text { Pool }\end{array}$ & Enhanced & - & - & - & Similar & Similar \\
\hline
\end{tabular}

* Articles performing long term expansion studies; \# Articles performing 3D studies.

Abbreviations: ADSCs, Adipose Derived Stem Cells; PRP, Platelet Rich plasma; FBS, Fetal bovine serum; Chondr, Chondrogenic; Adipo., Adipogenic; Osteo., Osteogenic.

\section{MSC+PRP: assessment of biological effects (Tabs. 1-3)}

\section{Proliferation: PRP and MSCs large expansion in CMOs}

The goal of these studies was to establish the best conditions for large-scale expansion of MSCs in cell manufacturing facilities in terms of safety, cost and time. The main goal was to substitute with PRP the xenogenic component of cell expansion, i.e. FBS (fetal bovine serum). 23 articles out of the 57 selected for this review perform long term expansion studies, and are indicated with * in Table 1,2 and 3. These studies primarily calculate cell population doublings through cell passages and population doubling times. They also check MSCs viability at high passages by testing CFU-f (colony-forming unit-fibroblast), phenotype, differentiation capacity and even chromosomal stability and senescence markers. In all the articles, PRP increases the number of cell population dou- blings, and decreases the time necessary for the population to duplicate. Of note, methodological differences inter studies, including initial cell seeding concentration, MSC passage number conditions, renewal of the medium, and time of the experiment difficult comparisons.

Importantly, PRP delays the appearance of the

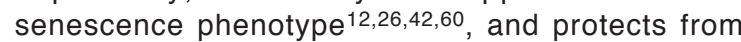
chromosomal instability longer than FBS, which has traditionally been used in MSC laboratory cultures.

\section{Tissue engineering}

In order to assess MSCs+PRP application in tissue engineering, 3D proliferation studies in different biomaterials used for the development of tissue grafts have been performed.

These studies are displayed with "\#” in Table 1 and 2. PRP can be incorporated in a gel or powdered form to the 3D scaffold, generally used for bone or cartilage tissue engineering. Other studies examine 
Table 2. Cell culture studies performed with Bone Marrow derived Stem Cells and Platelet Rich Plasma.

\begin{tabular}{|c|c|c|c|c|c|c|c|}
\hline \multirow[b]{4}{*}{$\begin{array}{l}\text { Author, year, } \\
\text { [reference] }\end{array}$} & \multirow[b]{4}{*}{$\begin{array}{l}\text { Platelet count } \\
\text { Pool or single } \\
\text { donor }\end{array}$} & \multicolumn{5}{|c|}{ BONE MARROW STEM CELLS } & \\
\hline & & \multirow[b]{3}{*}{ Proliferation } & \multirow[b]{3}{*}{ Migration } & \multicolumn{3}{|c|}{ BIOLOGICAL EFFECTS (PRP vs FBS) } & \\
\hline & & & & \multirow[b]{2}{*}{$\begin{array}{l}\text { Immune } \\
\text { modulation }\end{array}$} & \multicolumn{3}{|c|}{ Stemness } \\
\hline & & & & & Chondr. & Adipo. & Osteo. \\
\hline $\begin{array}{l}\text { P.H. Warnke } \\
2013 \text { [19] }^{\#}\end{array}$ & Pool & Enhanced & - & - & - & Similar & Similar \\
\hline $\begin{array}{l}\text { Jonsdottir- } \\
\text { Buch 2013[20]* }\end{array}$ & - & Enhanced & - & Similar & Similar & Similar & Similar \\
\hline $\begin{array}{l}\text { Schallmoser } \\
2013[21]\end{array}$ & $\begin{array}{l}\text { Moderate (3.8x) } \\
\text { Pool }\end{array}$ & Enhanced & - & - & - & - & - \\
\hline $\begin{array}{l}\text { Leotot } \\
2013[22]^{\#}\end{array}$ & $\begin{array}{l}\text { High }(4 x) \\
\text { Pool }\end{array}$ & Enhanced & - & - & - & - & Enhanced \\
\hline $\begin{array}{l}\text { Copland } \\
2013 \text { [23] }\end{array}$ & $\begin{array}{l}\text { High }(4 x) \\
\text { Pool }\end{array}$ & Enhanced & - & $\begin{array}{l}\text { Enhanced } \\
\text { when } \\
\text { fibrinogen } \\
\text { depletion }\end{array}$ & - & - & - \\
\hline Vogl 2013 [24] & $\begin{array}{l}\text { Moderate }(3.9 x) \\
\text { Pool }\end{array}$ & Enhanced & - & - & - & - & similar \\
\hline $\begin{array}{l}\text { Mojica-Henshaw } \\
2013 \text { [25] }\end{array}$ & $\begin{array}{l}\text { High }(4.3 x) \\
\text { Pool }\end{array}$ & Enhanced & - & - & Similar & Similar & Similar \\
\hline $\begin{array}{l}\text { Griffiths } \\
2013[26]^{*}\end{array}$ & Pool & Enhanced & & - & - & - & - \\
\hline $\begin{array}{l}\text { Gottipamula } \\
2012 \text { [27] }^{\star}\end{array}$ & Pool & Enhanced & - & Decreased & Enhanced & Similar & Enhanced \\
\hline $\begin{array}{l}\text { Fekete } \\
2012[28]^{\star}\end{array}$ & Pool & Enhanced & - & - & Similar & Similar & Similar \\
\hline $\begin{array}{l}\text { Teixeira } \\
2012[29]^{\#}\end{array}$ & Single donor & Enhanced & Enhanced & - & Enhanced & Similar & Similar \\
\hline $\begin{array}{l}\text { Walenda } \\
2012[30]^{\star \#}\end{array}$ & $\begin{array}{l}\text { Super high }(8.4 x) \\
\text { Pool }\end{array}$ & Enhanced & - & & Similar & Similar & Similar \\
\hline $\begin{array}{l}\text { Ben Azouna } \\
2012 \text { [31] }\end{array}$ & $\begin{array}{l}\text { Moderate (3.8x) } \\
\text { Pool }\end{array}$ & - & - & - & Similar & Similar & Similar \\
\hline $\begin{array}{l}\text { Murphy MB } \\
\text { et al } 2012 \text { [32] }\end{array}$ & $\begin{array}{l}\text { High }(4 x) \\
\text { Single donor }\end{array}$ & Enhanced & Enhanced & - & - & - & - \\
\hline $\begin{array}{l}\text { Fekete } \\
2012 \text { [33] }\end{array}$ & $\begin{array}{l}\text { High }(\geq 4 x) \\
\text { Pool }\end{array}$ & - & - & - & Similar & Similar & Similar \\
\hline Cho 2011 [34] & $\begin{array}{l}\text { High }(4.65 x) \\
\text { Single donor }\end{array}$ & Enhanced & - & - & - & - & - \\
\hline Xia 2011 [35] & $\begin{array}{l}\text { High }(5 x) \\
\text { Single donor }\end{array}$ & Enhanced & - & - & - & Decreased & Enhanced \\
\hline $\begin{array}{l}\text { Flemming } \\
2011 \text { [36] }\end{array}$ & Pool & Enhanced & - & Similar & - & - & - \\
\hline $\begin{array}{l}\text { Abdelrazik } \\
2011[37]^{\star}\end{array}$ & $\begin{array}{l}\text { Super high (10x) } \\
\text { Pool }\end{array}$ & Enhanced & - & Decreased & - & - & - \\
\hline $\begin{array}{l}\text { Goedecke } \\
2011 \text { [38] }\end{array}$ & $\begin{array}{l}\text { Low }(\leq 1 x) \\
\text { Single donor }\end{array}$ & Enhanced & Decreased & - & - & Similar & Similar \\
\hline $\begin{array}{l}\text { Lange } \\
2011[39]\end{array}$ & - & - & - & - & - & Decreased & - \\
\hline $\begin{array}{l}\text { Horn } \\
2010[40]^{\star}\end{array}$ & $\begin{array}{l}\text { Super high }(6.2 x) \\
\text { Pool }\end{array}$ & Enhanced & - & - & - & Similar & Enhanced \\
\hline
\end{tabular}


Table 2. (cont.) Cell culture studies performed with Bone Marrow derived Stem Cells and Platelet Rich Plasma.

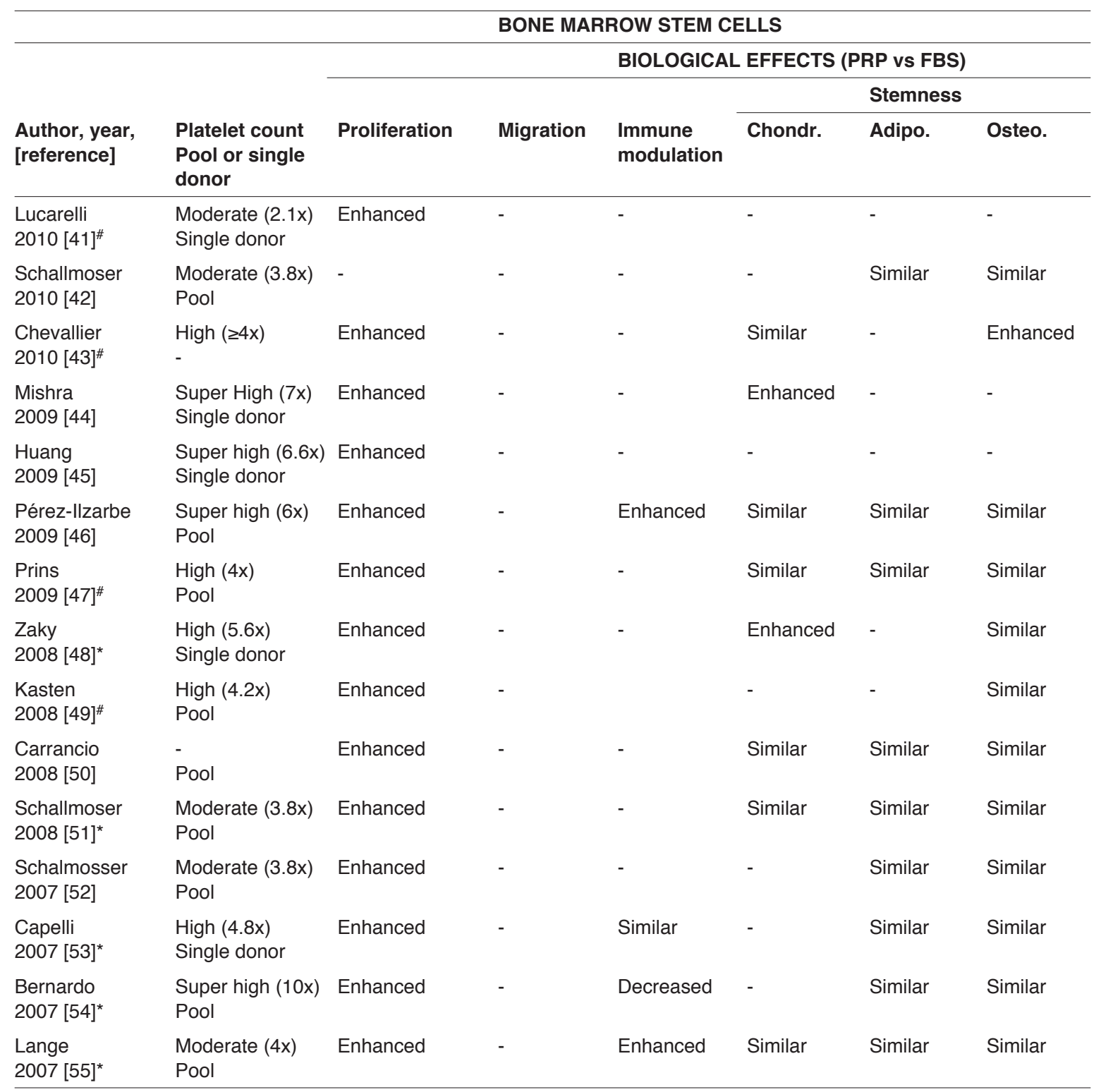

${ }^{*}$ Articles performing long term expansion studies; \#Articles performing 3D studies Abbreviations: BMSCs, Bone Marrow derived Stem Cells; PRP, Platelet Rich plasma; FBS, Fetal bovine serum; Chondr., Chondrogenic; Adipo., Adipogenic; Osteo., Osteogenic.

MSCs-scaffold constructs with culture medium supplemented with PRP, and observed not only enhanced cell proliferation but improved cell loading into the scaffolds ${ }^{49}$. PRP benefits have also been reported in terms of cell adhesion and colonization of the biomaterial scaffold ${ }^{29}$.

\section{MSC migration}

MSC migration is investigated in few studies ${ }^{11,29,32,38}$ all but one showed enhanced MSC migration in PRP comparing to FBS ${ }^{29,32}$. Moreover, Mur- phy ${ }^{32}$ et al. have compared ucPRP (umbilical cord PRP), aPRP (adult PRP), aPPP and FBS effect in MSC migration and found that all forms of human plasma were much more effective in promoting cell migration than FBS.

\section{Cell differentiation}

MSCs characteristically differentiate into multiple mesoderm-derived cell types including adipocytes, chondrocytes and osteoblasts. Aiming to develop articular therapies by combining PRP and MSCs, Mishra 
Table 3. Cell culture studies performed with Bone Marrow derived Stem Cells and Adipose Derived Stem Cells or Umbilical Cord Derived Mesenchymal Stem Cells (UCMSCs) and Platelet Rich Plasma.

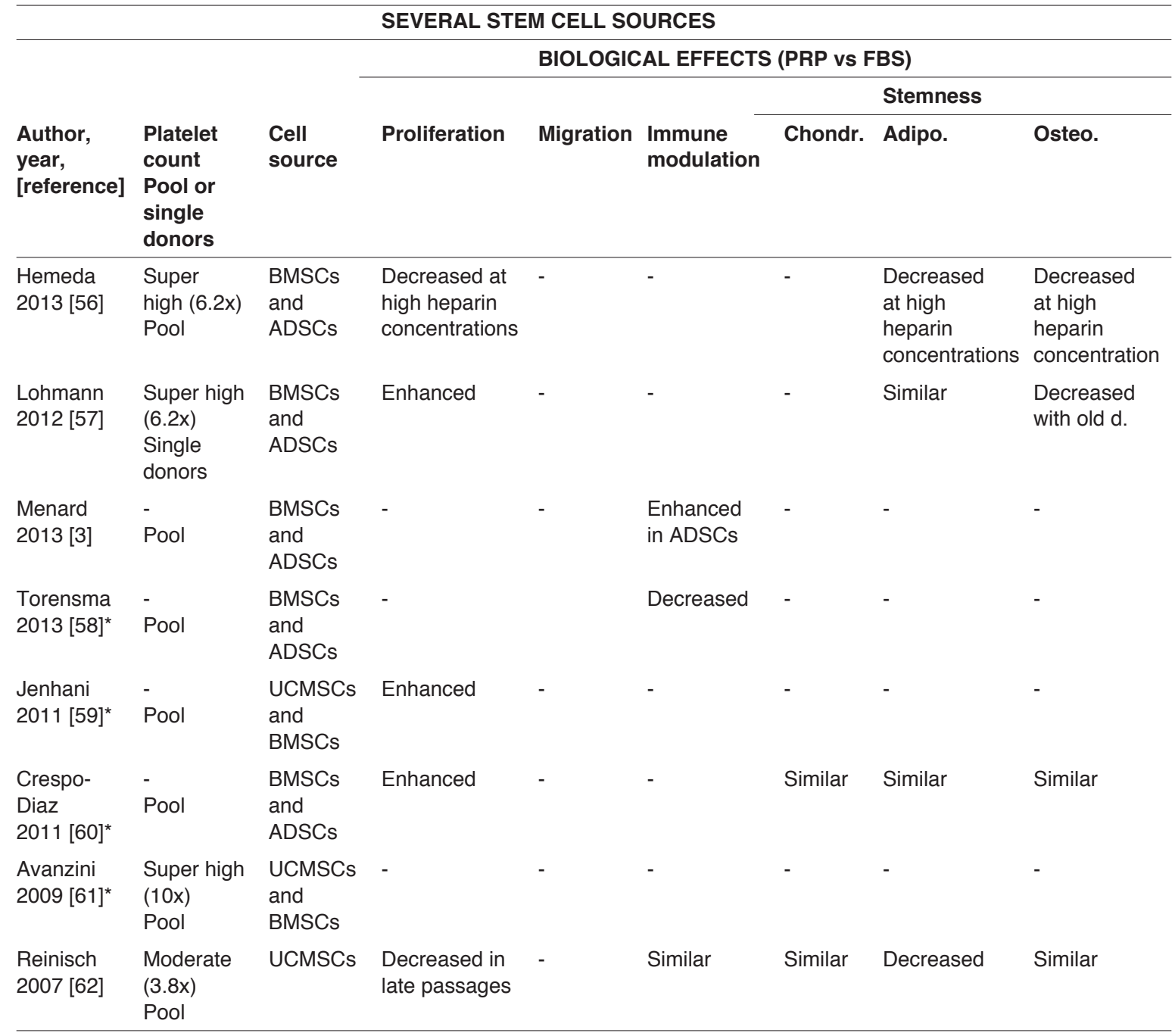

${ }^{*}$ Articles performing long term expansion studies

Abbreviations: ADSCs, Adipose Derived Stem Cells; BMSCs, Bone Marrow derived Stem Cells; UCMSCs, Umbilical Cord Derived Mesenchymal Stem Cells; PRP: Platelet Rich plasma; FBS: Fetal bovine serum; Chondr.: Chondrogenic; Adipo.: Adipogenic; Osteo.: Osteogenic.

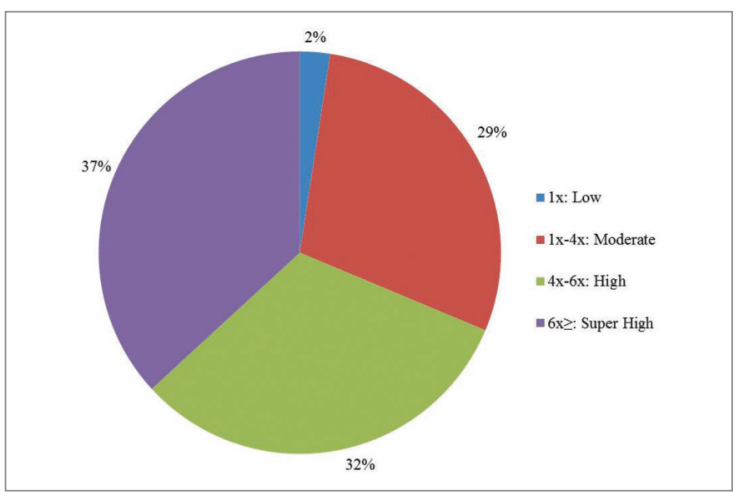

Figure 1. Sectors illustrating the use of different PRP formulations (according to De Long Classification [ref. 5]) in vitro studies of mesenchymal stem cells and PRP. et al. ${ }^{44}$ showed that buffered PRP enhanced the expression of chondrogenic markers, such as Sox9 and Aggrecan. These findings were corroborated in further studies $7,8,12,27,29,47$ that showed enhanced chondrogenic differentiation, and extracellular cartilage matrix synthesis in the presence of PRP. Likewise, Shih et al. ${ }^{12}$ also proved that chondrogenic differentiation was enhanced and maintained through cell passages in PRP cultures comparing to FCS cultures. Moreira Teixeira ${ }^{29}$ proved that chondrogenic differentiation in dextran based scaffolds was enhanced by the addition of PRP in the form of platelet lysate (PL). Interestingly PRP did not hinder chondrogenic differentiation in any of the studies reviewed here.

Besides, PRP did not interfere with osteogenic differentiation and most authors found similar osteogenic 
differentiation capacity when using one or the other supplement (PRP versus FBS). Albeit few studies have shown that PRP enhanced MSCs osteogenic differentiation in 2D culture ${ }^{14,27,35,40}$ and in 3D cultures ${ }^{9,22,43}$. Interestingly, Hemeda et al. ${ }^{56}$ found reduced osteogenic differentiation when MSCs where cultured with PRP with high heparine concentrations which were used to avoid PRP clotting. Also, Lohmann et al. ${ }^{23}$ found less osteogenic differentiation capacity in stem cells cultured with PRP obtained from old donors.

In the same trend, adipogenic differentiation was similar with PRP or FBS. Yet, Chieregato ${ }^{14}$ observed enhanced adipogenic differentiation of ADSCs cultured with PRP, as well as Cervelli ${ }^{10}$, but in the latter case only when PRP was combined with insulin. On the contrary, Reinisch ${ }^{62}$ and Lange ${ }^{39}$ observed decreased adipogenesis when ADSCs and BMSCs where cultured with PRP, respectively. As occurred in chondrogenesis and osteogenesis assays, high heparin concentrations interfered with adipogenic differentiation ${ }^{56}$. The fact that PRP supplementation preserves multipotency of MSCs, and does not interfere with any lineage differentiation, establishes it as a suitable substitute for FBS.

\section{Modulation of the immune response}

MSCs can modulate the immune response by suppressing the proliferation of $\mathrm{T}$ lymphocytes, as shown in coculture models ${ }^{15}$. Furthermore, MSCs can inhibit proliferation and function of other adaptive immune cells including B cells, NK cells and dendritic cells ${ }^{55}$. Additionally MSCs alter the cytokine secretion profile of immune cells generating an anti-inflammatory phenotype. MSCs cultured with PRP (in the form of platelet lysate or releasate) preserve their immuneprivileged potential as shown by suppression of T-cell proliferation $20,36,53,55,62$ and activation ${ }^{46}$. Interestingly, the immune potential of MSCs was enhanced when cultured with fibrinogen-depleted PRP ${ }^{23}$. In fact, fibrinogen compromised the ability of MSCs to up-regulate indoleamine dioxygenase that negatively correlates with T-cell proliferation ${ }^{23}$.

Remarkably, super-high concentration of platelets (10x) impaired MSC inhibitory effect on T-cells ${ }^{37,54}$ and NK-cells, and stimulate secretion of IL-6, IL-8 and RANTES while decreasing PGE2 ${ }^{37}$.

\section{Discussion}

As shown in this review, in vitro research in the field "PRP+MSC" is focused on two main areas, first optimization of the manufacturing process for mesenchymal stem cell therapy purposes, and second expanding the knowledge about how PRP modifies MSCs behavior for translational purposes, that is to say enhancement of PRP therapies, or design of the new combination products primarily based on "PRP+ MSCs".
Three central mechanisms are investigated in the in vitro models including: proliferation, migration, and the maintenance of the differentiation potential. In addition, the influence of PRP in the immune-modulatory properties of MSCs as well as the appearance of the senescence phenotypehas been explored.

There is no doubt that any PRP formulation (L-PRP, pure PRP, lysate, releasate) activates MSC proliferation in a controlled non-tumorigenic manner, a property that is of great value not only for cell manufacturing, but also for the clinical applications. Also, PRP is a useful tool to be incorporated in tissue engineering as it acts as a stimulator for cells to proliferate and colonize the scaffold.

Merely three studies ${ }^{11,29,32}$ have explored the potential of PRP to induce MSC migration. The chemotactic properties of PRP on MSCs can be partially attributed to the chemokine SDF-1a (stromal derived factor 1, CXCL12) stored in the alpha granules ${ }^{63,64}$. This cytokine acts via CXCR-4 promoting cell migration and homing. Whether PRP enhances precursor cell migration is crucial in order to augment the efficiency of bone marrow stimulating techniques, i.e. drilling to subchondral bone as performed in knee pathology and rotator cuff 65,66 . These conditions illustrate the importance of augmenting cell migration, and the relevance of translational research in PRPs in getting the essential knowledge to design successful therapies. Thus, the need is clear to augment our knowledge, and introduce procedural modifications that may help to control the migration, proliferation and differentiation of these cells for successful healing.

Regarding differentiation, our Review shows that PRP maintains stemness and does not hinder differentiation to bone, cartilage or fat, when the appropriate factors are added to the culture media.

Cell cultures are a useful tool to design models that help to elucidate molecular mechanisms, and identify specific molecules involved therein. However, linking specific molecules with biological mechanisms is challenging, and results are not conclusive yet. For example, proliferation illustrates how difficult it is to link detailed molecules with biological mechanisms. Aiming to identify the main factors involved in proliferation, Horn et al. ${ }^{40}$ denoted PDGF-AB and IGF as responsible for proliferation. Accordingly, Huang et al. ${ }^{45}$ separated PRP in different fractions according to their molecular weight, and found that the fractions in which there was higher PDGF-AB and TGF- $\beta 1$ content were the ones that enhanced MSC proliferation the most. The contribution of TGF- $\beta 1$ to proliferation was confirmed by Cho HS et al. ${ }^{34}$. Notwithstanding, Lohmann et al. ${ }^{57}$ reported a lack of correlation between the concentrations of PDGF-AB, bFGF, TGF$\beta 1$ and IGF-1, and proliferation. Fekete et al. ${ }^{28}$ found that proliferation decreased when inhibition of PDGFBB and b-FGF was performed. Moreover, the strongest inhibition was observed when combinations of anti-bFGF and anti-PDGF-BB or anti-bFGF + antiTGF $\beta+$ anti-PDG-BB were used. On the contrary, when different combinations of recombinant PDGF$\mathrm{BB}, \mathrm{bFGF}$ and TGF- $\beta$ were added to platelet poor 
plasma, cell proliferation wasn't promoted ${ }^{14}$. This is in accordance with similar experiments performed in tenocytes ${ }^{67}$. This paradox can be explained assuming that the proliferative potential stems from molecular redundancy, and a delicate balance between multiple pro- and anti-proliferative molecules ${ }^{68}$.

Likewise, increasing PRP percentage in cultures does not necessarily increase proliferation; $10 \%$ PRP seemed to be the optimal $19,21,36,57$, and increasing up to $30 \%$ PRP didn't enhance proliferation but lowered it compared to FBS.

These results are relevant for cell manufacturing organizations where large-scale expansion of MSCs is performed according to Good Manufacturing Practice (GMP) procedures. To date, conventional MSC culture systems involve the use of about $10 \%$ of FBS (fetal bovine serum) in culture medium, but recently there is an emerging interest to avoid its use, due to the risk of xenogeneic immune reactions provoked by FBS antigens ${ }^{18,57}$. Also, it has been reported that FBS can be implicated in prion transmission, and its therapeutic use is not recommended by European legislation ${ }^{69}$. Furthermore, it is complicated to use FBS in a controlled, reproducible manner, because of its complex composition, with varying efficacy. Human platelet rich plasma (PRP), in the form of platelet lysates (HPL) or releasates, have emerged as possible substitutes for FBS because of their autologous, non-immunogenic features, and adequate physiological composition. Indeed, currently PRPs are commercialized for cell expansion purposes and even lysates resulting from expired platelet bags obtained from blood banks seem to be adequate as substitutes of FBS and provide the same good results as freshly isolated PRPs ${ }^{20}$.

In the present review, we have identified several sources of variability in PRP technology that may influence the efficiency of large-scale expansion, and also the above described biological mechanisms. First, the formulation i.e. platelet and leukocyte count in a given volume of plasma, second, the activation procedure, and lastly the inter-individual variability. The composition of PRP depends on the preparation methodology, i.e. single versus double spinning ${ }^{70,71}$. Final platelet concentration ranges from $1 \mathrm{x}$ above baseline ${ }^{35}$ to $12 x^{18}$. The most commonly used platelet concentration in vitro ranges between $3 x$ and $6 x$. It is known that there is a variation in platelet content produced not only by preparation methods, but influenced by inter-and intra-donor variations. The latter include factors related to patient state, i.e. hydration status, inflammation, lipemia, diet or circadian rythms ${ }^{72}$.

To avoid inter-donor variations in PRPs and optimize reproducibility, several author use pooled PRP from at least ten donors ${ }^{55}$. Alternatively, other authors ${ }^{27,36}$ pool PRPs from donors of the three blood groups, whereas others pool blood from the $\mathrm{O}$ group in order to avoid the presence of blood group determinants and isoagglutinins ${ }^{21}$. In this review, $30 \%$ of the articles use single donor's PRP whereas $70 \%$ use pooled PRPs.

The age of donors is a crucial parameter to be considered because it significantly affects PRP biology.
For instance, MSCs proliferation is higher with PRP from young donors while MSCs cultured with PRP from elder donors can have diminished proliferation, present a senescence phenotype ${ }^{34,57}$, and hindered differentiation capabilities to specific lineages ${ }^{57}$.

In clinical applications, L-PRPs often contain concentration of leukocytes above peripheral blood. Although they contribute to increase the pool of GFs, they also release active cytokines that are primarily catabolic or inflammatory, e.g. IL1 $\beta$, TNF- $\alpha$, IFN- $\gamma^{73}$. Moreover leukocytes release degrading enzymes, mainly lysozymes and elastases that compromise the stability of GFs as well as gelatinases and metalloproteases, catabolic for collagen proteins.

Clinicians have to be careful when making sense of laboratory results, because cells in vitro do not mimic correctly the in vivo environment, and can only provide partial explanations of PRP biology. In fact, the in vivo conditions involve the impact of PRP on several cell types present in the host tissues; also relevant is the dynamic influence of PRP in the innate immune response, and in precursor cell migration. These are few among the simultaneously occurring events that cannot be mimicked in cell culture models. But despite important limitations of in vitro studies, we still can learn some lessons. Any formulation of PRP stimulates MSC activation, but currently there is no link with a single molecule and proliferation or migration or differentiation. The molecular pool released from PRPs is very complex, and experimental design for in vitro experiments to achieve meaningful results is challenging. Many gaps of knowledge need to be addressed in vitro in order to achieve enough information useful for translational purposes.

\section{Acknowledgements}

Work in the laboratory of the authors is supported by Ministerio de Economia y Competitividad (grant no IPT-2012-0743) and by Basque Government (SAIO12-PE12BF007).

\section{Conflict of interests}

None reported.

\section{References}

1. Hoogduijn MJ, Popp F, Verbeek R, Masoodi M, Nicolaou A, Baan C, Dahlke MH. The immunomodulatory properties of mesenchymal stem cells and their use for immunotherapy. Int Immunopharmacol. 2010;10(12):1496-1500.

2. Caplan Al. Mesenchymal stem cells. J Orthop Res. 1991;9(5) 641-650.

3. Menard C, Pacelli L, Bassi G, et al. Clinical-grade mesenchymal stromal cells produced under various good manufacturing practice processes differ in their immunomodulatory properties: standardization of immune quality controls. Stem Cells Dev. 2013;22(12):1789-1801.

4. Brown PT, Handorf AM, Jeon WB, Li WJ. Stem cell-based tis- 
sue engineering approaches for musculoskeletal regeneration. Curr P harm Des. 2013;19(19):3429-3445.

5. Padulo J, Oliva F, Frizziero A, Maffulli N. Muscle, Ligaments and Tendons Journal. Basic principles and recommendations in clinical and field science research. MLTJ. 2013:4:250-252.

6. DeLong JM, Russell RP, Mazzocca AD. Platelet-rich plasma: the PAW classification system. Arthroscopy. 2012;28(7):9981009.

7. Van Pham P, Bui KH, Ngo DQ, et al. Activated platelet-rich plasma improves adipose-derived stem cell transplantation efficiency in injured articular cartilage. Stem Cell Res Ther. 2013;4(4):91.

8. Hildner F, Eder MJ, Hofer K, et al. Human platelet lysate successfully promotes proliferation and subsequent chondrogenic differentiation of adipose-derived stem cells: a comparison with articular chondrocytes. J Tissue Eng Regen Med. 2013.

9. Chen L, Lu X, Li S, Sun Q, Li W, Song D. Sustained delivery of BMP-2 and platelet-rich plasma-released growth factors contributes to osteogenesis of human adipose-derived stem cells. Orthopedics. 2012;35(9):e1402-1409.

10. Cervelli V, Scioli MG, Gentile P, Doldo E, Bonanno E, Spagnoli LG, Orlandi A. Platelet-rich plasma greatly potentiates insulininduced adipogenic differentiation of human adipose-derived stem cells through a serine/threonine kinase Akt-dependent mechanism and promotes clinical fat graft maintenance. Stem Cells TransI Med. 2012;1(3):206-220.

11. Sell SA, Wolfe PS, Ericksen JJ, Simpson DG, Bowlin GL. Incorporating platelet-rich plasma into electrospun scaffolds for tissue engineering applications. Tissue Eng Part A. 2011;17 (21-22):2723-2737.

12. Shih DT, Chen JC, Chen WY, Kuo YP, Su CY, Burnouf T. Expansion of adipose tissue mesenchymal stromal progenitors in serum-free medium supplemented with virally inactivated allogeneic human platelet lysate. Transfusion. 2011;51(4):770-778.

13. Cholewa D, Stiehl T, Schellenberg A, et al. Expansion of adipose mesenchymal stromal cells is affected by human platelet lysate and plating density. Cell Transplant. 2011;20(9):14091422.

14. Chieregato K, Castegnaro S, Madeo D, Astori G, Pegoraro M, Rodeghiero F. Epidermal growth factor, basic fibroblast growth factor and platelet-derived growth factor-bb can substitute for fetal bovine serum and compete with human platelet-rich plasma in the ex vivo expansion of mesenchymal stromal cells derived from adipose tissue. Cytotherapy. 2011;13(8):933-943.

15. Castegnaro S, Chieregato K, Maddalena M, et al. Effect of platelet lysate on the functional and molecular characteristics of mesenchymal stem cells isolated from adipose tissue. Curr Stem Cell Res Ther. 2011;6(2):105-114

16. Blande IS, Bassaneze V, Lavini-Ramos C, et al. Adipose tissue mesenchymal stem cell expansion in animal serum-free medium supplemented with autologous human platelet lysate. Transfusion. 2009;49(12):2680-2685.

17. Kakudo N, Minakata T, Mitsui T, Kushida S, Notodihardjo FZ, Kusumoto K. Proliferation-promoting effect of platelet-rich plasma on human adipose-derived stem cells and human dermal fibroblasts. Plast Reconstr Surg. 2008;122(5):1352-1360.

18. Kocaoember A, Kern S, Klüter H, Bieback K. Human AB serum and thrombin-activated platelet-rich plasma are suitable alternatives to fetal calf serum for the expansion of mesenchymal stem cells from adipose tissue. Stem Cells. 2007;25(5):1270-1278.

19. Warnke PH, Humpe A, Strunk D, et al. A clinically-feasible protocol for using human platelet lysate and mesenchymal stem cells in regenerative therapies. J Craniomaxillofac Surg. 2013;41(2):153-161.

20. Jonsdottir-Buch SM, Lieder R, Sigurjonsson OE. Platelet lysates produced from expired platelet concentrates support growth and osteogenic differentiation of mesenchymal stem cells. PLoS One. 2013;8(7):e68984.

21. Schallmoser K, Strunk D. Generation of a pool of human platelet lysate and efficient use in cell culture. Methods Mol Biol. 2013;946:349-362.

22. Leotot J, Coquelin L, Bodivit G, Bierling P, Hernigou P, Rouard $\mathrm{H}$, Chevallier N. Platelet lysate coating on scaffolds directly and indirectly enhances cell migration, improving bone and blood vessel formation. Acta Biomater. 2013;9(5):6630-6640.

23. Copland IB, Garcia MA, Waller EK, Roback JD, Galipeau J. The effect of platelet lysate fibrinogen on the functionality of MSCs in immunotherapy. Biomaterials. 2013;34(32):7840-7850.

24. Vogl M, Fischer J, Jäger M, Zilkens C, Krauspe R, Herten M. Can thrombin - activated platelet releasate compensate the age-induced decrease in cell proliferation of MSC? J Orthop Res. 2013;31(11):1786-1795.

25. Mojica-Henshaw MP, Jacobson P, Morris J, Kelley L, Pierce J, Boyer M, Reems JA. Serum-converted platelet lysate can substitute for fetal bovine serum in human mesenchymal stromal cell cultures. Cytotherapy. 2013;15(12):1458-1468.

26. Griffiths S, Baraniak PR, Copland IB, Nerem RM, McDevitt TC Human platelet lysate stimulates high-passage and senescent human multipotent mesenchymal stromal cell growth and rejuvenation in vitro. Cytotherapy. 2013;15(12):1469-1483.

27. Gottipamula S, Sharma A, Krishnamurthy S, Majumdar AS, Seetharam RN. Human platelet lysate is an alternative to fetal bovine serum for large-scale expansion of bone marrow-derived mesenchymal stromal cells. Biotechnol Lett. 2012;34(7): 1367-1374.

28. Fekete N, Rojewski MT, Fürst D, Kreja L, Ignatius A, Dausend J, Schrezenmeier H. GMP-compliant isolation and large-scale expansion of bone marrow-derived MSC. PLoS One. 2012;7 (8):e43255.

29. Moreira Teixeira LS, Leijten JC, Wennink JW, et al. The effect of platelet lysate supplementation of a dextran-based hydrogel on cartilage formation. Biomaterials. 2012;33(14):3651-3661.

30. Walenda G, Hemeda H, Schneider RK, Merkel R, Hoffmann $B$, Wagner W. Human platelet lysate gel provides a novel three dimensional-matrix for enhanced culture expansion of mesenchymal stromal cells. Tissue Eng Part C Methods. 2012;18 (12):924-934.

31. Ben Azouna N, Jenhani F, Regaya Z, Berraeis L, Ben Othman T, Ducrocq E, Domenech J. Phenotypical and functional characteristics of mesenchymal stem cells from bone marrow: comparison of culture using different media supplemented with human platelet lysate or fetal bovine serum. Stem Cell Res Ther. 2012;3(1):6.

32. Murphy MB, Blashki D, Buchanan RM, Yazdi IK, Ferrari M, Simmons PJ, Tasciotti E. Adult and umbilical cord blood-derived platelet-rich plasma for mesenchymal stem cell proliferation, chemotaxis, and cryo-preservation. Biomaterials. 2012;33(21):5308-5316.

33. Fekete N, Gadelorge M, Fürst D, et al. Platelet lysate from whole blood-derived pooled platelet concentrates and apheresis-derived platelet concentrates for the isolation and expansion of human bone marrow mesenchymal stromal cells: production process, content and identification of active components. Cytotherapy. 2012;14(5):540-554.

34. Cho HS, Song IH, Park SY, Sung MC, Ahn MW, Song KE. Individual variation in growth factor concentrations in plateletrich plasma and its influence on human mesenchymal stem cells. Korean J Lab Med. 2011;31(3):212-218.

35. Xia W, Li H, Wang Z, et al. Human platelet lysate supports ex vivo expansion and enhances osteogenic differentiation of human bone marrow-derived mesenchymal stem cells. Cell Biol Int. 2011;35(6):639-643.

36. Flemming A, Schallmoser K, Strunk D, Stolk M, Volk HD, Seifert M. Immunomodulative efficacy of bone marrow-derived 
mesenchymal stem cells cultured in human platelet lysate. $J$ Clin Immunol. 2011;31(6):1143-1156.

37. Abdelrazik H, Spaggiari GM, Chiossone L, Moretta L. Mesenchymal stem cells expanded in human platelet lysate display a decreased inhibitory capacity on T- and NK-cell proliferation and function. Eur J Immunol. 2011;41(11):3281-3290.

38. Goedecke A, Wobus M, Krech M, Münch N, Richter K, Hölig K, Bornhauser M. Differential effect of platelet-rich plasma and fetal calf serum on bone marrow-derived human mesenchymal stromal cells expanded in vitro. J Tissue Eng Regen Med. 2011;5(8):648-654.

39. Lange C, Brunswig-Spickenheier B, Eissing L, Scheja L. Platelet lysate suppresses the expression of lipocalin-type prostaglandin D2 synthase that positively controls adipogenic differentiation of human mesenchymal stromal cells. Exp Cell Res. 2012;318(18):2284-2296.

40. Horn P, Bokermann G, Cholewa D, Bork S, Walenda T, Koch C, Drescher W, et al. Impact of individual platelet lysates on isolation and growth of human mesenchymal stromal cells. Cytotherapy. 2010;12(7):888-898.

41. Lucarelli E, Beretta R, Dozza B, et al. A recently developed bifacial platelet-rich fibrin matrix. Eur Cell Mater. 2010;20:13-23.

42. Schallmoser K, Bartmann C, Rohde E, et al. Replicative senescence-associated gene expression changes in mesenchymal stromal cells are similar under different culture conditions. Haematologica. 2010;95(6):867-874.

43. Chevallier N, Anagnostou F, Zilber S, et al. Osteoblastic differentiation of human mesenchymal stem cells with platelet lysate. Biomaterials. 2010;31(2):270-278.

44. Mishra A, Tummala P, King A, Lee B, Kraus M, Tse V, Jacobs CR. Buffered platelet-rich plasma enhances mesenchymal stem cell proliferation and chondrogenic differentiation. Tissue Eng Part C Methods. 2009;15(3):431-435.

45. Huang Q, Wang YD, Wu T, Jiang S, Hu YL, Pei GX. Preliminary separation of the growth factors in platelet-rich plasma: effects on the proliferation of human marrow-derived mesenchymal stem cells. Chin Med J (Engl). 2009;122(1):83-87.

46. Pérez-llzarbe M, Díez-Campelo M, Aranda P, et al. Comparison of ex vivo expansion culture conditions of mesenchymal stem cells for human cell therapy. Transfusion. 2009;49(9): 1901-1910.

47. Prins HJ, Rozemuller H, Vonk-Griffioen S, Verweij VG, Dhert WJ, Slaper-Cortenbach IC, Martens AC. Bone-forming capacity of mesenchymal stromal cells when cultured in the presence of human platelet lysate as substitute for fetal bovine serum. Tissue Eng Part A. 2009;15(12):3741-3751.

48. Zaky SH, Ottonello A, Strada P, Cancedda R, Mastrogiacomo M. Platelet lysate favours in vitro expansion of human bone marrow stromal cells for bone and cartilage engineering. J Tissue Eng Regen Med. 2008;2(8):472-481.

49. Kasten P, Vogel J, Beyen I, Weiss S, Niemeyer P, Leo A, Lüginbuhl $R$. Effect of platelet-rich plasma on the in vitro proliferation and osteogenic differentiation of human mesenchymal stem cells on distinct calcium phosphate scaffolds: the specific surface area makes a difference. J Biomater Appl. 2008;23 (2):169-188.

50. Carrancio S, López-Holgado N, Sánchez-Guijo FM, et al. Optimization of mesenchymal stem cell expansion procedures by cell separation and culture conditions modification. Exp Hematol. 2008;36(8):1014-1021.

51. Schallmoser K, Rohde E, Reinisch A, et al. Rapid large-scale expansion of functional mesenchymal stem cells from unmanipulated bone marrow without animal serum. Tissue Eng Part C Methods. 2008;14(3):185-196.

52. Schallmoser K, Bartmann C, Rohde E, et al. Human platelet Iysate can replace fetal bovine serum for clinical-scale expansion of functional mesenchymal stromal cells. Transfusion. 2007;47(8):1436-1446.
53. Capelli C, Domenghini M, Borleri G, et al. Human platelet lysate allows expansion and clinical grade production of mesenchymal stromal cells from small samples of bone marrow aspirates or marrow filter washouts. Bone Marrow Transplant. 2007;40(8):785-791.

54. Bernardo ME, Avanzini MA, Perotti C, et al. Optimization of in vitro expansion of human multipotent mesenchymal stromal cells for cell-therapy approaches: further insights in the search for a fetal calf serum substitute. J Cell Physiol. 2007;211(1): 121-130.

55. Lange C, Cakiroglu F, Spiess AN, Cappallo-Obermann H, Dierlamm J, Zander AR. Accelerated and safe expansion of human mesenchymal stromal cells in animal serum-free medium for transplantation and regenerative medicine. J Cell Physiol. 2007;213(1):18-26.

56. Hemeda H, Kalz J, Walenda G, Lohmann M, Wagner W. Heparin concentration is critical for cell culture with human platelet lysate. Cytotherapy. 2013;15(9):1174-1181.

57. Lohmann M, Walenda G, Hemeda $\mathrm{H}$, et al. Donor age of human platelet lysate affects proliferation and differentiation of mesenchymal stem cells. PLoS One. 2012;7(5):e37839.

58. Torensma R, Prins HJ, Schrama E, Verwiel ET, Martens AC Roelofs $\mathrm{H}$, Jansen BJ. The impact of cell source, culture methodology, culture location, and individual donors on gene expression profiles of bone marrow-derived and adipose-derived stromal cells. Stem Cells Dev. 2013;22(7):1086-1096.

59. Jenhani F, Durand V, Ben Azouna N, Thallet S, Ben Othmen T, Bejaoui M, Domenech J. Human cytokine expression profile in various conditioned media for in vitro expansion bone marrow and umbilical cord blood immunophenotyped mesenchymal stem cells. Transplant Proc. 2011;43(2):639-643.

60. Crespo-Diaz R, Behfar A, Butler GW, et al. Platelet lysate consisting of a natural repair proteome supports human mesenchymal stem cell proliferation and chromosomal stability. Cell Transplant. 2011;20(6):797-811.

61. Avanzini MA, Bernardo ME, Cometa AM, et al. Generation of mesenchymal stromal cells in the presence of platelet lysate: a phenotypic and functional comparison of umbilical cord bloodand bone marrow-derived progenitors. Haematologica. 2009;94(12):1649-1660.

62. Reinisch A, Bartmann C, Rohde E, Schallmoser K, Bjelic-Radisic V, Lanzer G, Linkesch W, Strunk D. Humanized system to propagate cord blood-derived multipotent mesenchymal stromal cells for clinical application. Regen Med. 2007;2(4): 371-382.

63. Andia I, Sánchez M, Maffulli N. Basic science: Molecular and biological aspects of PRP therapies. Operative Techniques in Orthopedics. 2012;22:3-9.

64. Andia I, Maffulli N.Platelet-rich plasma for managing pain and inflammation in osteoarthritis. Nat Rev Rheumatol. 2013;9 (12):721-730.

65. Milano G, Deriu L, Sanna Passino E, et al. Repeated platelet concentrate injections enhance reparative response of microfractures in the treatment of chondral defects of the knee: an experimental study in an animal model. Arthroscopy. 2012;28(5):688-701.

66. Milano G, Saccomanno MF, Careri S, Taccardo G, De Vitis R, Fabbriciani C. Efficacy of marrow-stimulating technique in arthroscopic rotator cuff repair: a prospective randomized study. Arthroscopy. 2013;29(5):802-810.

67. Anitua E, Andia I, Sanchez M, et al. Autologous preparations rich in growth factors promote proliferation and induce VEGF and HGF production by human tendon cells in culture. J Orthop Res. 2005;23:281-286.

68. Andia I, Abate M. Platelet-rich plasma: underlying biology and clinical correlates. Regen Med. 2013;8(5):645-658.

69. Doucet C, Ernou I, Zhang Y, Llense JR, Begot L, Holy X, Lataillade JJ. Platelet lysates promote mesenchymal stem cell ex- 
pansion: a safety substitute for animal serum in cell-based therapy applications. J Cell Physiol. 2005;205(2):228-236.

70. Andia I, Abate M. Platelet-rich plasma injections for tendinopathy and osteoarthritis. Int J Clin Rheumatol. 2012;7(4):1-16.

71. Gupta S, Reviakine I. Platelet activation profiles on TiO2: effect of Ca2+binding to the surface. Biointerphases. 2012;7(1-4):28.
72. Boswell SG, Cole BJ, Sundman EA, Karas V, Fortier LA Platelet-rich plasma: a milieu of bioactive factors. Arthroscopy. 2012;28(3):429-439.

73. Mazzocca AD, McCarthy MB, Chowaniec DM, et al. Plateletrich plasma differs according to preparation method and human variability. J Bone Joint Surg Am. 2012;94(4):308-316. 